\title{
Effect of Methanolic and Phenolic Extracts of Nigella sativa Seeds on Testicular Expression Levels of inhibin alpha and beta Genes in Mature Male Wistar Rats
}

\author{
Jabbar Jasim Hamady ${ }^{1 *}$, Kamal Gahzi Ganim², Zainab Sattar Ali ${ }^{1}$ \\ ${ }^{1}$ Deptartment Biology, College of Science, Wasit University, Iraq. \\ ${ }^{2}$ Deptartment Theriogenology, College of Veternary Medicine, Al-Qadisiya University, Iraq.
}

\begin{tabular}{|c|c|}
\hline ARTICLE INFO & ABSTRACT \\
\hline $\begin{array}{l}\text { Article history: } \\
\text { Received on: } 19 / 03 / 2016 \\
\text { Revised on: } 12 / 04 / 2016 \\
\text { Accepted on: } 10 / 05 / 2016 \\
\text { Available online: } 30 / 08 / 2016\end{array}$ & $\begin{array}{l}\text { To examine the effect of crude methanolic extract and phenolic compounds obtained from Nigella sativa seeds } \\
\text { on testicular expression levels of inhibin- } \alpha,-\beta \mathrm{A} \text {, and }-\beta \mathrm{B} \text { subunits of intact mature male rats, thirty males were } \\
\text { randomly assigned to three equal groups }(\mathrm{C}, \mathrm{M} \text {, and } \mathrm{P}) \text {. Males were orally administered with distal water, } \\
\text { methanolic extract of } N \text {. sativa seed at the dose of } 1.0 \mathrm{~g} / \mathrm{kg} \text { b.w., and phenolic extract of } N \text {. sativa seed at the } \\
\text { dose of } 0.3 \mathrm{~g} / \mathrm{kg} \text { b. w., daily for } 18 \text { days. At the end of treatment period, male rats were anesthetized by single }\end{array}$ \\
\hline $\begin{array}{l}\text { Key words: } \\
\text { Inhibin, Nigella sativa, } \\
\text { fertility, testis. }\end{array}$ & $\begin{array}{l}\text { injection of thiopental }(100 \mathrm{mg} / \mathrm{kg} \text {, i.p.), sacrificed, and testes were removed. Samples from testicular tissues } \\
\text { were quickly dipped in DEPC solution and frozen at }-80^{\circ} \mathrm{C} \text { until gene expression levels assessment of inhibin } \\
\text { subunits by using semi-quantitative RT-PCR analyses. Male rats that have been treated with phenolic } \\
\text { compounds (P group) registered marked increase of all inhibin subunits compared with those treated with } \\
\text { methanolic extract, which they were also higher than that of control males. It can be concluded that phenolic } \\
\text { compounds of } N \text {. sativa seeds have the more efficient role in reproductive functions than methanolic extract of } \\
N \text {. sativa seed. }\end{array}$ \\
\hline
\end{tabular}

\section{INTRODUCTION}

Nigella sativa, from the Ranunculacea family, is one of the most widely used herbal medicines for the treatment of various diseases. Its pharmacological properties are thought to be due to Nigellone and Thymoquinone contents which have been reported to include anti-inflammatory, anti-cancer, anti-diabetic, anti-microbial, anti-histaminic, anti-infertility and hypotensive effects (Mukhallad et al., 2009; Alenzi et al., 2010). Thymoquinone is the active compound of the essential oil with anti-oxidative effect that works as a scavenger of various radical oxygen species including superoxide radical anion and hydroxyl radicals through different mechanisms as well as to its ability to significantly boost the human immune system, if taken over time(Haq et al. 1999; Mansour et al., 2002; Badary et al., 2003; Mahgoub 2003Salem, 2005). Numerous studies have shown that

\footnotetext{
* Corresponding Author

Email:jbr20042002@yahoo.com
}

the seed and oil of black seeds are characterized by a very low degree of toxicity (Gali-Muhtasib et al., 2006). Hormones are chemicals that transfer information and instructions between cells in animals hence described as the body's chemical messengers, these regulate growth and development, control the function of various tissues, support reproductive functions, and regulate metabolism in a slow manner (Melmed and Conn, 2005).

FSH and LH mainly regulate inhibin production in the ovary; both gonadotropins stimulate its production in granulosa cells and in the corpus luteum, respectively (Zhang et al., 1987; Tsonis et al., 1987).

Inhibins and activins are are members of the TGF- $\beta$ superfamily. Inhibins are heterodimeric glycoproteins composed of a unique $\alpha$-subunit linked with one of $\beta$-subunits ( $\beta A$ and $\beta B$ ) by disulphide bonds. Hetero-dimerization of the $\alpha$-subunit with either $\beta A$ - or $\beta B$-subunit generates dimeric inhibin $A(\alpha-\beta A)$ and inhibin $\mathrm{B}(\alpha-\beta \mathrm{B})$, respectively. These factors are the strongly inhibitors of pituitary FSH secretion (Burger, 1993; Knight and Glister, 2001). 
The proportion of the $\alpha$-subunit in the tissue where it is synthesized, as well as in circulation, is higher than that of the $\beta$ subunit (Knight et al., 1989). Activins are group of growth and differentiation factors that have a variety of functions. Activins are synthesized in a large number of tissues and are considered paracrine rather endocrine factors (Welt and Crowley, 1998).

It has been found that daily oral administration of $\mathrm{N}$. sativa oil improved reproductive efficiency of hyperlipidemic rats (Samir Bashandy, 2007). Mukhallad et al (2009) reported an increased spermatogenesis of male rats treated with the aqueous extracts of N. sativa. In addition, El-Tahomi et al (2010) registered an improvement of the semen characteristics and reduction of free radicals in the seminal plasma of male rats treated with a mixture of equal quantities from radish, rocket and black cumin (N. sativa) meals. Therefore, this study was conducted to examine the effect of crude methanolic extract and phenolic compounds obtained from Nigella sativa seeds on fertility potential through evaluation of testicular expression levels of inhibin- $\alpha,-\beta A$, and $-\beta B$ subunits of mature male rats.

\section{MATERIALS AND METHODS}

\section{Experimental Animals}

Adult male Wister rats (average weight was $245 \pm 10 \mathrm{~g}$.), were obtained from the National Laboratory Animal Center and reared under controlled conditions (12L:12D cycles at $20-22 \mathrm{C}^{\circ}$ ) and fed standard laboratory food (19\% protein ratio and 3000 kilocalories energy) and drinking water.

\section{Preparation of methanolic and phenolic extracts}

$N$. sativa seeds were purchased from the local market and classified by State Board for Seed Testing and Classification, Ministry of Agriculture, Iraq (SBSTC). Phenolic extract has been prepared according to Ribereau-Gayon (1972), whereas methanolic extract has been prepared according to Harborne (1984).

\section{Experimental Design}

Thirty mature male rats were randomly assigned to three equal groups. All males were orally administered, for 30 days, with distal water (control group), phenolic extract of $N$. sativa seed at the dose of $0.3 \mathrm{~g} / \mathrm{kg}$ bw (P group), and methanolic extract of $N$. sativa seed at the dose of $1 \mathrm{~g} / \mathrm{kg}$ bw (M group). Twenty four hours after the last treatment, male rats were anaesthetized with thiopental (100 mg/ kg, i.p.), sacrificed and testis were removed. Samples from testis of rats in all groups have been quickly dipped in DEPC solution, and frozen at $-80{ }^{\circ} \mathrm{C}$ for determination of inhibin alpha and beta gene expression levels by semi-quantitative RT-PCR analyses.

\section{RT-PCR analysis}

RNA has been extracted from the testis tissues according to the protocol mentioned by Surzcki (2000). Master Mix for each sample was prepared according to the recommendations of the manufacturers, and the same procedure followed in the determination of endogenous gene and target genes. PCR products have been transferred into gel electrophoresis apparatus for obtaining and determining the studied genes bands. This step has been done by mixing $2 \mu \mathrm{l}$ of loading dye with $10 \mu \mathrm{l}$ of each PCR product (each sample) and $2 \mu \mathrm{l}$ of ladder. The mixture was loaded into gel lanes.

Finally, gel electrophoresis apparatus was turned on at 90 $\mathrm{mV}$ for 40 minutes. Gel documentation step has been carried out according to the protocol mentioned by Surzcki (2000).

\section{Statistical Analysis}

The results were expressed as mean \pm standard deviation of the mean (SDM). Comparisons were performed using one way analysis of variance (ANOVA1) and newman- keuls to test all groups' unpaired values. Differences were considered to be significant at the level of $\mathrm{P}<0.05$. The statistical analysis was carried out using the GraphPad Prism (SAS Institute, Inc., USA, 2011).

\section{RESULTS}

\section{Concentration of RNA in the testis}

The result of total RNA concentration in testis tissues clarified in figure (1) revealed significant $(\mathrm{P} \leq 0.05)$ increase in mRNA concentration of $\mathrm{P}$ extract treated males compared with $\mathrm{M}$ extract treated males, which they also showed significant $(\mathrm{P} \leq 0.05)$ increase in comparison with control males.

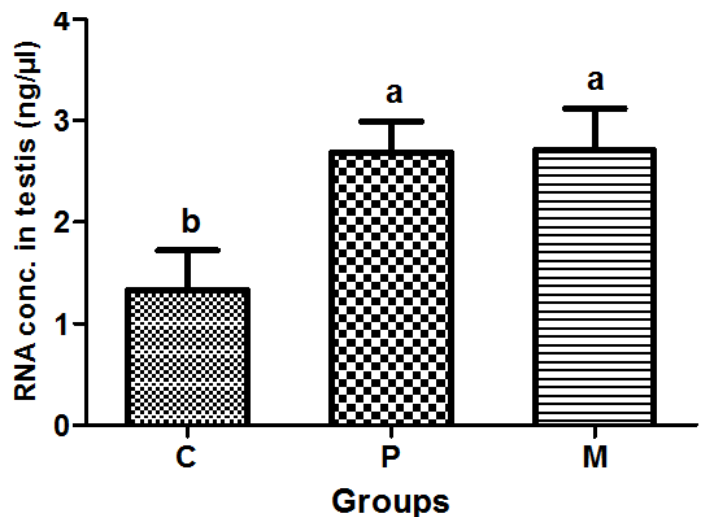

Fig 1: Effect of methanolic and phenolic extract of $N$. sativa seed on RNA concentration $(\mathrm{ng} / \mu \mathrm{l})$ in testis tissues of adult male Wistar rats.

The results represented as mean $\pm \mathrm{SE}$.

Different small letters denotes the present of significant differences $(\mathrm{P}<0.05)$ between groups.

C: control male rats orally administered with distal water for 30 days. $\mathrm{P}$ : male rats treated with $\mathrm{P}$ extract of $N$. sativa seed $(0.3 \mathrm{~g} / \mathrm{kg} \mathrm{bw})$ for 30 days. $\mathrm{M}$ : male rats treated with $\mathrm{M}$ extract of $N$. sativa seed $(1 \mathrm{~g} / \mathrm{kg} \mathrm{bw})$ for 30 days.

\section{RNA normalization}

The present findings showed that the optical density of each sample at $260 \mathrm{~nm}$ and $280 \mathrm{~nm}$ as well as the dilution folds needed to prepare the final concentration $(100 \mathrm{ng} / \mu \mathrm{l})$ necessary to complete the following steps of semi-quantitative RT-PCR, were within the normal range, where the ratio between the two optical densities were more than 1.8 and less than 2.2. 


\section{mRNA expression level of beta actin}

Beta actin gene expression level has been used as a corresponding gene for normalization and quantification of inhibin- $\alpha,-\beta a$, and $-\beta b$ genes (figure-2).

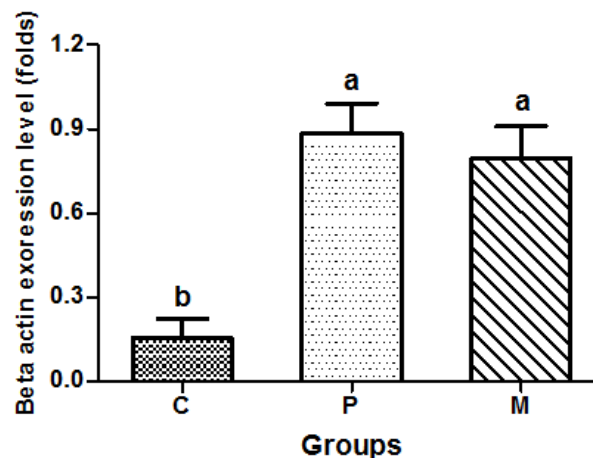

Fig 2: Effect of methanolic and phenolic extract of $N$. sativa seed on mRNA expression level of Beta actin (folds) in testis tissues of adult male Wistar rats.

The results represented as mean $\pm \mathrm{SE}$.

Different small letters denotes the present of significant differences $(\mathrm{P}<0.05)$ between groups.

C: control male rats orally administered with distal water for 30 days.

P: male rats treated with $\mathrm{P}$ extract of $N$. sativa seed $(0.3 \mathrm{~g} / \mathrm{kg} \mathrm{bw})$ for 30 days.

$\mathrm{M}$ : male rats treated with $\mathrm{M}$ extract of $N$. sativa seed $(1 \mathrm{~g} / \mathrm{kg} \mathrm{bw})$ for 30 days.

\section{mRNA Expression Level of inhibin alpha in testis tissues}

mRNA expression level of inhibin- $\alpha$ subunit gene, illustrated in figures (3), of $\mathrm{P}$ extract treated males testes increased significantly $(\mathrm{P} \leq 0.05)$ in comparison with that recorded by $M$ extract treated males testes, which was also significantly $(\mathrm{P} \leq 0.05)$ higher than that of control males throughout the experimental period.

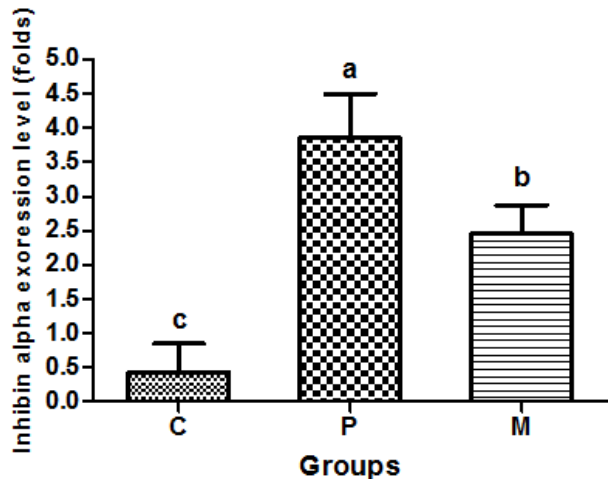

Fig 3: effect of methanolic and phenolic extract of $N$. sativa seed on mRNA expression level of inhibin alpha subunit (folds) in testis tissues of adult male Wistar rats.

The results represented as mean \pm SE.

Different small letters denotes the present of significant differences $(\mathrm{P}<0.05)$ between groups.

C: control male rats orally administered with distal water for 30 days.

P: male rats treated with P extract of $N$. sativa seed $(0.3 \mathrm{~g} / \mathrm{kg} \mathrm{bw})$ for 30 days. M: male rats treated with $\mathrm{M}$ extract of $N$. sativa seed $(1 \mathrm{~g} / \mathrm{kg} \mathrm{bw})$ for 30 days.

\section{mRNA Expression Level of inhibin beta-A and beta-B in testis tissues}

The results of mRNA expression level of inhibin $\beta$ a gene illustrated in figures (4) recorded insignificant $(\mathrm{P} \geq 0.05)$ changes between $\mathrm{P}$ and $\mathrm{M}$ groups but they were significantly $(\mathrm{P} \leq 0.05)$ higher than control. Figure (5) showed significant $(\mathrm{P} \leq 0.05)$ increase of $\beta b$ expression level in $\mathrm{P}$ group than that of control and $M$ groups, whereas $M$ group also recorded significant $(P \leq 0.05)$ increase compared with control.

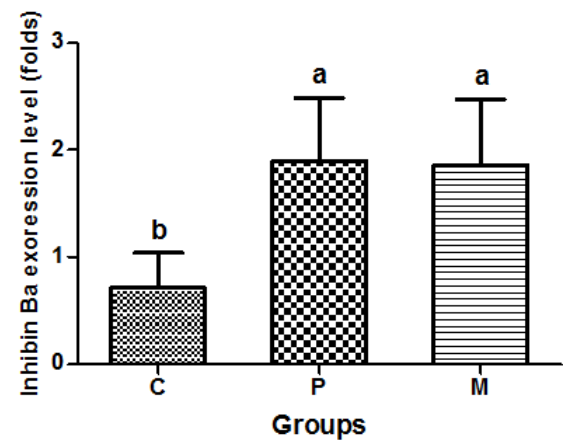

Fig 4: Effect of methanolic and phenolic extract of $N$. sativa seed on mRNA expression level of inhibin Beta-A subunit (folds) in testis tissues of adult male Wistar rats.

The results represented as mean $\pm \mathrm{SE}$.

Different small letters denotes the present of significant differences $(\mathrm{P}<0.05)$ between groups.

$\mathrm{C}$ : control male rats orally administered with distal water for 30 days.

$\mathrm{P}$ : male rats treated with $\mathrm{P}$ extract of $N$. sativa seed $(0.3 \mathrm{~g} / \mathrm{kg} \mathrm{bw})$ for 30 days. $\mathrm{M}$ : male rats treated with $\mathrm{M}$ extract of $N$. sativa seed $(1 \mathrm{~g} / \mathrm{kg}$ bw) for 30 days.

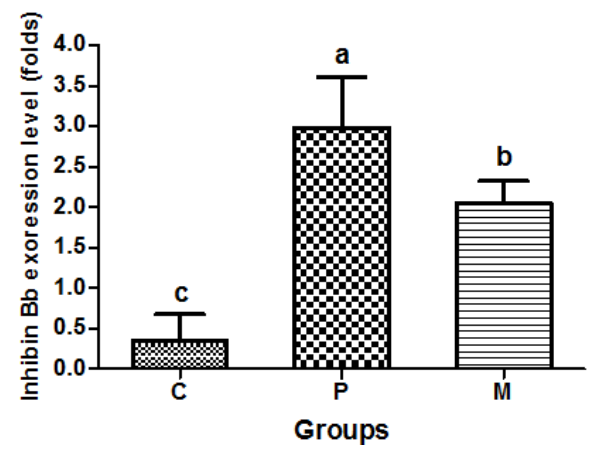

Fig 5: Effect of methanolic and phenolic extract of $N$. sativa seed on mRNA expression level of inhibin Beta-B subunit (folds) in testis tissues of adult male Wistar rats.

The results represented as mean $\pm \mathrm{SE}$.

Different small letters denotes the present of significant differences $(\mathrm{P}<0.05)$ between groups.

C: control male rats orally administered with distal water for 30 days.

P: male rats treated with P extract of $N$. sativa seed $(0.3 \mathrm{~g} / \mathrm{kg}$ bw) for 30 days. M: male rats treated with $\mathrm{M}$ extract of $N$. sativa seed $(1 \mathrm{~g} / \mathrm{kg}$ bw) for 30 days.

\section{DISCUSSION}

The increase of testicular alpha subunit expression level in treated groups could reflect the high production of inhibins. On the other hand, the increase of expression levels of beta-B and unchanged beta-A unit expression reflect the high production of inhibin-B but not inhibin-A nor activins by Sertoli cells, since these cells are responsible for the production of inhibins and activins in response to high levels of pituitary gonadotropin secretion (Melmed and Conn, 2005). In the findings, treating male rats with $\mathrm{M}$ and $\mathrm{P}$ extracts of Nigella sativa revealed significant inhibin subunits genes expression levels elevations in comparison with control males, particularly male rats that treated with $\mathrm{P}$ extract. Most properties of the whole black seeds or their extracts are mainly attributed to the quinone constituents present in the 
volatile oil, of which thymoquinone, about $27-57 \%$, is the most abundant component (Ali and Blunden, 2003; Gali-Muhtasib et al., 2006). Thymoquinone was reported to re-establish spermatogenesis after testicular injury caused by chronic toluene exposure in rats (Kanter, 2011). A nother study by Arak and Assi (2011) reported that adult rats exposed to $10 \mathrm{mg} / \mathrm{kg}$ of lead acetate caused a significant reduction on ovarian function and the treatment of $100 \mathrm{mg} / \mathrm{kg}$ of Nigella sativa caused significant enhancement on the reproductive function with a decrease in number and diameter of Graafian follicles in comparison to the normal structure. The increased inhibin- $\alpha$ subunit especially in Nigella sativa P extract treated male's testicular tissues could be a response to the high activity of Sertoli cells, since these cells activities were always under the influence of FSH, where it has been evidenced that Nigella sativa extract increased the circulatory levels of FSH in mature male rats (Al-Sa'aidi et al., 2009). On the other hand, although FSH secretion is primarily regulated by $\mathrm{GnRH}$ and gonadal steroids, there are other paracrine and endocrine factors such as pituitary activin and follistatin and testicular inhibin $\beta$ that only regulate FSH without affecting $\mathrm{LH}$ secretion and synthesis. Activin stimulates FSH $\beta$ gene transcription through activation of the Smad family of proteins. The testicular protein inhibin $\beta$, secreted by Sertoli cells, competes with activin for binding to the activin receptor, preventing the initiation of signaling of Smads and thus decreasing FSH gene transcription. Sertoli cells thus appear to mediate the biologic actions of both circulating hormones and the paracrine regulatory factors. The presence of activins in spermatocytes at defined stages, in unfertilized and fertilized ova, and in various organs throughout embryogenesis suggests that they must be important to development (Mitrani et al., 1990). The inhibin secretion by Sertoli cells in response to FSH stimulation is so important, since inhibin will furtherly suppresses pituitary FSH, and therefore can act as a tumor suppressor, and has paracrine functions in the gonads (Bernard et al., 2001; Wood and Strauss, 2002).

\section{REFERENCES}

Alenzi FQ, El-Bolkiny YS, Salem ML. Protective effects of Nigella sativa oil and thymoquinone against toxicity induced by the anticancer drug cyclophosphamide. Br J Biomed Sci, 2010; 67(1):20-28.

Ali BH, Blunden G, Pharmacological and toxicological properties of Nigella sativa. Phytother Res, 2003; 17:299-305.

Al-Sa'aidi JAA, Al-Khuzai ALD, Al-Zobaydi NFH. Effect of alcoholic extract of Nigella sativa on fertility in male rats. Iraqi J Vet Sci, 2009; 23(Supp. II):123-128.

Arak JK, Assi MA. Effect of Nigella sativa L. seeds on ovaries function in adult Rats treated with Lead Acetate. Al-Anbar Medical J, 2011; 9(1): 59-70.

Badary OA, Taha RA, Gamalel-Din AM, Abdel-Wahab MH. Thymoquinone is a potent superoxide anion scavenger. Drug Chem Toxicol, 2003; 26(2): 87-98.

Bernard DJ, Chapman SC, Woodruff TK. Mechanisms of inhibin signal transduction. Recent Prog Horm Res, 2001; 56:417-50.

Burger H. Clinical review 46: Clinical utility of inhibin measurements. J Clin Endocrinol Metab, 1993; 76:1391-6.

Gali-Muhtasib H, Roessner A, Schneider-Stock R. Thymoquinone: a promising anti-cancer drug from natural sources. Int $\mathbf{J}$ Biochem Cell Biol, 2006; 38:1249-1253.
Haq A, Lobo PI, Al-Tufail M, Rama NR, Al-Sedairy ST. Immunomodulatory effect of Nigella sativa proteins fractionated by ion exchange chromatography. Int J Immunopharmacol, 1999; 21: 283-95.

Harborne JB. (1984). Phytochemical Methods: A Guide to Modern Techniques of plant Analysis. Chapman and Hall, London, UK., pp: 1-34.

Kanter M. Thymoquinone reestablishes spermatogenesis after testicular injury caused by chronic toluene exposure in rats. Toxicol Ind Health, 2011; 27: 155-166.

Knight P, Beard A, Wrathall J, et al. Evidence that the bovine ovary secretes large amounts of monomeric inhibin alpha subunit and its isolation from bovine follicular fluid. J Mol Endocrinol, 1989; 2:189-200.

Knight P, Glister C. Potential local regulatory functions of inhibins, activins and follistatin in the ovary. Reproduction, 2001; 121: 503-12.

Mahgoub AA. Thymoquinone protects against experimental colitis in rats. Toxicol Lett, 2003; 143(2): 133-143.

Mansour MA, Nagi MN, El-khatib AS, Al- Bekairi AM. Effects of thymoquinone on antioxidant enzyme activities, lipid peroxidation and DT-diaphorase in different tissues of mice: a possible mechanism of action. Cell Biochem Funct, 2002; 20(2): 143-151.

Melmed S, Conn PM. (2005). Endocrinology: Basic and Clinical Principles. $2^{\text {nd }}$ ed., Humana Press. Totowa, New Jersey, USA. Pp: 405-419.

Mitrani E, Ziv T, Thomsen G, et al. Activin can induce the formation of axial structures and is expressed in the hypoblast of the chick. Cell, 1990; 63:495-501.

Mukhallad AM, Mohamad MJM, Hatham D. Effects of black seeds (Nigella sativa) on spermatogenesis and fertility of male albino rats. Res J Med Medical Sci, 2009; 4: 386-390.

Ribereau-Gayon P. (1972). Plant phenolics. Oliver and Boyd, Hafner press, Edinburgh.

Salem ML. Immunomodulatory and therapeutic properties of the Nigella sativa L. seed. Internat Immunopharmacol, 2005; 5: 17491770 .

Surzycki S. (2000): Basic Techniques in Molecular biology. Springer-Verlag Publisher ISBN 3-540-66678-8.

Tsonis C, Hillier S, Baird D. Production of inhibin bioactivity by human granulosa-lutein cells: stimulation by $\mathrm{LH}$ and testosterone in vitro. J Endocrinol, 1987; 112:R11-4.

Welt C, Crowley W. Activin: an endocrine or paracrine agent? Eur J Endocrinol, 1998; 139:469-71.

Wood JR, Strauss JF. Multiple signal transduction pathways regulate ovarian steroidogenesis. Rev Endocr Metab Disord, 2002; 3:3346.

Zhang Z, Carson R, Herington A, et al. Follicle-stimulating hormone and somatomedin-C stimulate inhibin production by rat granulosa cells in vitro. Endocrinology 1987; 120:1633-8.

Samir Bashandy AE. Effects of fixed oil of Nigella sativa on male fertility in normal and Hyperlipidemic rats. Int J Pharmacol, 2007; 3: 27-33.

Mukhalad AM, Mohamad MJ, Darka H. Effects of black seeds (Nigella sativa) on spermatogenesis and fertility of male albino rats. Res J Med Med Sci, 2009; 4: 386-390.

El-Tahomi MM, El-Nattat WS, El-Kady RI. The benifical effects of Nigella sativa, Raphanus sativus and Eruca sativa seed cakes to improve male rabbit fertility, immunity and production. J Am Sci, 2010; 6: 1247-1255.

\section{How to cite this article:}

Jabbar Jasim Hamady, Kamal Gahzi Ganim, Zainab Sattar Ali. Effect of Methanolic and Phenolic Extracts of Nigella sativa Seeds on Testicular Expression Levels of inhibin alpha and beta Genes in Mature Male Wistar Rats. J App Pharm Sci, 2016; 6 (08): 118-121. 